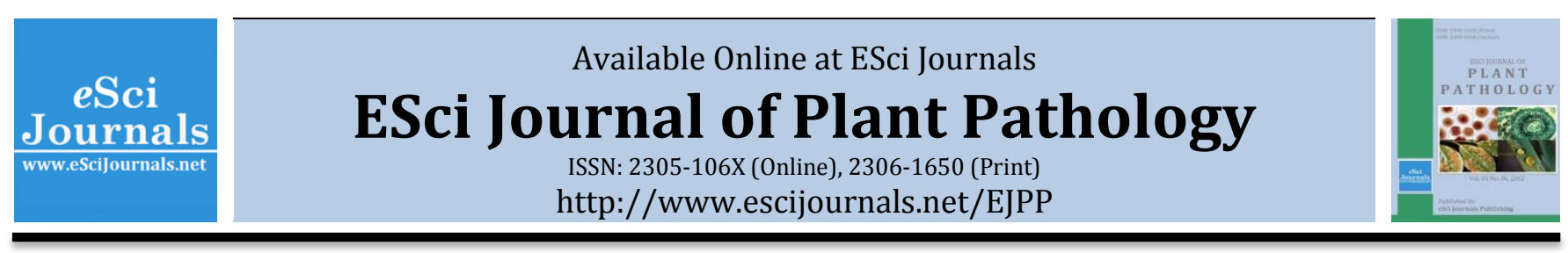

\title{
BIOCONTROL POTENTIALS OF PLANT GROWTH PROMOTING RHIZOBACTERIA AGAINST FUSARIUM WILT DISEASE OF CUCURBIT
}

\author{
Avinash T. Shanthi, Ravishankar R. Vittal \\ Department of Studies in Microbiology, University of Mysore, Manasagangothri, Mysore, Karnataka, India.
}

\begin{abstract}
A B S T R A C T
Fusarium spp., are the major soil-borne as well as seed borne pathogens causing wilt and rot diseases in more than 80 plant species including cucurbits. Fusarium spp., causes up to $100 \%$ yield loss in the worldwide. Eleven isolates including three standard isolates were tested both in-vitro and in-vivo. In-vitro assay was done by dual culture method. Maximum inhibition was in case of Fusarium solani by Bacillus cereus MIC5. Sarratia spp. MIC1 antagonized the $F$. verticillodes and F. solani2. P. aeruginosa MIC2 inhibits all tested isolates F. oxysporum1. P. aeruginosa MTCC2581 suppressed the radial growth rate of $F$. oxysporum2. The two systemic fungicides used were chlorothalonil + mefenoxam (1000 ppm) and carbendazim $(75 \mathrm{ppm}$ to $500 \mathrm{ppm})$ which checked the growth of $F$. oxysporum. Carbendazim was more effective compared to mefenoxam + chlorothalonil at all tested concentrations. The crude extract of $P$. aeruginosa MIC2 developed in chloroform: methanol $(9: 1)$ showed a metabolite at $\mathrm{R}_{\mathrm{f}}-0.77$ which it may be 2,4- diacetylphloroglucinol (DAPG), a broad-spectrum antimicrobial agent. Increased cucurbit seeds germination and seedling vigour was observed in B. amyloliquefaciens MIC6 (68\% \& 1576) and P. aeruginosa MTCC2581 (70\% \& 1929) in primed seeds. Further $P$. aeruginosa MTCC2581 can be tested in the field against the Fusarium wilt.
\end{abstract}

Keywords: Fusarium spp., PGPR, fungicides, biological control, DAPG.

\section{INTRODUCTION}

India is the second largest producer of vegetables in the world with $2.8 \%$ of total cropped area and $13.38 \%$ of total vegetable production (Kundu, 2012). Being the largest cash crop, about 4,929,400 million tonnes of cucurbits were produced in India (FAOSTAT, 2010). Fusarium spp., are the major soil-borne as well as seed borne pathogens causing wilt and rot diseases in more than 80 plant species including cucurbits (Mahfooz et al., 2011). Fusarium spp., causes up to $100 \%$ yield loss in the worldwide (Santos et al., 2002). In cucurbitaceae $F$. oxysporum is the frequent pathogen in cucumber seeds (Farrag and Moharam, 2012). Fusarium spp., cause the crown rot, foot rot and fruit rot of squash as well as pumpkin (Zitter, 1996). Pathogens survive in soil and seed in the form of chlamydospores for many years. Mycelia enter the epidermal tissues invading through roots, extend to the vascular bundles and form spores in plants (Chehri et al., 2010). The pathogen causes seed

\footnotetext{
* Corresponding Author:

Email: raivittal@gmail.com

(C) 2013 ESci Journals Publishing. All rights reserved.
}

abortion and rot, necrosis, reduction or elimination of germination capacity as well as plant damage at later stages of plant growth resulting in development of the disease as systemic or local infection (Khanzada et al., 2002). The diseases can be controlled by using resistant cultivars, chemical fungicides as well as fumigants (Fravel et al., 2005) and biological control agents (Idris et al., 2007). Soil solarisation (Tamietti and Valentino, 2006), crop rotation and grafting (Zhao et al., 2011) are used to control the root diseases.

Fungicidal seed treatment may kill or inhibit seed borne pathogens that may form a protective zone around seeds to reduce seed decay and seedling wilt resulting in vigorous seedlings and emergence of seeds (Khanzada et al., 2002). In-vitro inhibition of $F$. solani was observed by such fungicides as, Aliette, Benlate and Carbendazim. Carbendazim completely inhibited seed borne infection of $F$. solani in bitter gourd, cucumber and bottle gourd. Root infection was completely controlled by Benlate and Carbendazim in bitter gourd (Sultana and Gaffer, 2010). Different fungicides were tested against the seed borne fungi $F$. moniliforme in wheat. The fungicides retarded 
the growth of fungi and increased the seedling number (Khanzada et al., 2002).

From the past three decades to minimize the use of the chemicals, synthetic fertilizers and pesticides sustainable agriculture was practiced as an ecofriendly concept. In sustainable agriculture soil borne pathogens can be controlled by biological agents like plant growth promoting rhizobacteria (PGPR) as they colonize host root and create competition for space as well as nutrition. PGPR is ecofriendly, stimulates the plant growth factors and reduces the incidence of crop diseases and supplies the nutrition for the growth of plant. P. ceparcia, P. fluorescence, B. polymyxa and B. subtilis used as biocontrol agents against Fusarium wilt of melon. Among them P. fluorescence shows highest reduction in the Fusarium wilt incidence and good antagonistic activity compared to control (Hamed et al., 2009). F. oxysporum causes root and crown rots in sorghum in world. Seventy eight isolates of PGPR were tested against $F$. oxysporum in-vitro and in greenhouse. Four isolates viz. Bacillus spp. KBE2-5, $B$. stearothermophilus KBE5-7, B. cereus KBE5-1 and $B$. cereus NAE5-5 suppressed disease by root colonization. F. oxysporum is managed by PGPR as compared to control (Idris et al., 2007). Bafti et al. (2005) reported that, Streptomyces olivaceus strain 115 antagonised $F$. oxysporum f.sp. melonis caused root rot and Fusarium wilt of cucurbits in Kerman Province, southeast of Iran. In green house soil treated with $S$. olivaceus reduction in wilt incidence was observed, as compared to control. In modern agriculture PGPR is used as bio-fertilizer as well as biological control agent against certain seed and soilborne plant pathogens. The present work relates to invitro and in-vivo evaluation of fungicides as well as effective use of PGPR against Fusarium.

\section{MATERIALS AND METHOD}

Microorganisms used: The eight PGPR isolates (Table 1) isolated from the rhizosphere samples of healthy Cucurbitaceae field soils were obtained from the culture collection of the Department of Studies in Microbiology, Manasagangothri, Mysore. Standard PGPR strains obtained from Microbial type culture collection (MTCC) Chandigarh, India, included Pseudomonas aeruginosa MTCC2581, Bacillus coagulans MTCC3543 and Bacillus subtilis MTCC2763, which were used as positive controls. The different Fusarium spp. were isolated from diseased cucurbitaceae field soil and materials on potato dextrose agar (PDA), incubated at $25^{\circ} \mathrm{C}$ for 5-6 days.

\section{In-vitro antagonistic activity}

Biological control: The in-vitro mycelial inhibition of Fusarium spp. was tested by dual culture technique as referred by Idris et al. (2009). Briefly each bacterial isolate was point inoculated at four sides, $3 \mathrm{~cm}$ apart from the center on the PDA plate and incubated at $35 \pm 2^{\circ}$ C for $24 \mathrm{~h}$. After $24 \mathrm{~h}$, six day old fungal culture was point inoculated at the center of the PDA plate, control plates were sealed with parafilm and incubated at $28 \pm 2^{\circ}$ C for 4-5 days. Inhibition per cent was calculated as follows.

$\%$ of Inhibition $=(\mathrm{R}-\mathrm{r}) / \mathrm{R} \times 100$

Where, $r$ is the radius of the fungal colony opposite to the bacterial colony and $\mathrm{R}$ is the maximum radius of the fungal colony away from the bacterial colony.

Fungicides: The carbendazim and chlorothalonil + mefenoxam fungicides were evaluated by poison food method against $F$. oxysporum. Different concentrations $(25,50,75,100,500,1000 \mathrm{ppm})$ of fungicides were added to molten PDA after sterilization and poured to 9 $\mathrm{cm}$ diameter petri plates. Six days old culture $5 \mathrm{~mm}$ mycelial disks were point inoculated at the center of the plate to check the toxicity. The plates without fungicides were maintained as control and incubated at $28 \pm 2^{\circ} \mathrm{C}$ for 4-5 days (Fravel et al., 2005).

\section{Antibiotic Production}

The antibiotic activity of selected PGPR isolates were assessed by extracting and testing toxicity of metabolites produced by them by the method of Ayyadurai et al. (2005). P. aeruginosa MIC2 was grown for $48 \mathrm{~h}$ in nutrient broth (NB) and centrifuged at 10,000 rpm for $10 \mathrm{~min}$. The filtrate was extracted three times by shaking with an equal volume of ethyl acetate (1:1 ratio). $P$. aeruginosa MIC2 culture extract were collected and dried in a rotary evaporator (Buchi, Switzerland). The extract residue was re-dissolved in ethyl acetate and stored in refrigerator at $4^{\circ} \mathrm{C}$. The residue was spotted in ethyl acetate on to thin layer chromatography plate (Silica gel $60 \mathrm{~F} 254,20 \times 20 \mathrm{~cm}, 0.2 \mathrm{~mm}$ thickness, Merck). The plate was chromatogrammed using chloroform: methanol (9:1) as solvent system. Later the plates were observed under UV light at $254 \mathrm{~nm}$.

\section{In-vivo evaluation of PGPR}

All PGPR strains were grown in NB for $48 \mathrm{~h}$ and centrifuged at $8000 \mathrm{rpm}$ for $5 \mathrm{~min}$ to get the pellet and washed with sterile distilled water. The concentration of PGPR inoculum were adjusted with sterile distilled water to $1 \times 10^{8} \mathrm{cfu} / \mathrm{ml}$ at $\mathrm{A}_{610} \mathrm{~nm}$ using UV-visible 
Table 1. In-vitro mycelia inhibition of Fusarium spp. by PGPR isolates from different cucurbitaceae crops.

\begin{tabular}{|c|c|c|c|c|c|c|c|}
\hline \multirow{2}{*}{ PGPR } & \multicolumn{7}{|c|}{ \% Inhibition } \\
\hline & F. graminarum & F. solani & F. oxysporum 1 & F. verticillodes & F. solani 2 & F. semitectem & F.oxysporum 2 \\
\hline & & 1 & & & & & \\
\hline Control & $74.0 \pm 0.57^{a}$ & $84.66 \pm 0.88^{a}$ & $74 \pm 0.57^{a}$ & $64 \pm 0.57^{a}$ & $46 \pm 0.57^{\mathrm{ab}}$ & $67.33 \pm 0.88^{\mathrm{a}}$ & $86.33 \pm 0.88^{a}$ \\
\hline Sarratia spp. MIC1 & 0 & 0 & $36.33 \pm 0.88^{\mathrm{cd}}$ & $52.36 \pm 0.85^{b}$ & $50.33 \pm 1.49 a$ & 0 & $15.63 \pm 1.68 \mathrm{~g}$ \\
\hline Pseudomonas aeruginosa MIC2 & $46.06 \pm 1.94^{b}$ & $44.86 \pm 0.92^{b}$ & $50.23 \pm 0.98^{b}$ & $42.3 \pm 1.35^{\mathrm{d}}$ & $35.3 \pm 2.4^{\mathrm{ab}}$ & 0 & $36.86 \pm 1.21^{\mathrm{d}}$ \\
\hline Bacillus cereus MIC3 & $43.73 \pm 1.32^{\mathrm{bc}}$ & $46.43 \pm 2.14^{b}$ & $29.33 \pm 1.61^{\mathrm{e}}$ & 0 & $44.1 \pm 2.68^{\mathrm{ab}}$ & 0 & $23.3 \pm 1.57^{f}$ \\
\hline Bacillus subtilis MIC4 & 0 & 0 & $30.13 \pm 0.78^{e}$ & 0 & 0 & 0 & 0 \\
\hline Bacillus cereus MIC5 & $27.0 \pm 1.15^{\mathrm{d}}$ & 0 & $32.10 \pm 1.87 \mathrm{de}$ & 0 & $49.86 \pm 10.92^{a}$ & $30.53 \pm 1.48^{c}$ & 0 \\
\hline Bacillus amyloliquefaciens MIC6 & $15.26 \pm 1.53^{\mathrm{e}}$ & 0 & 0 & $34.46 \pm 1.75^{\mathrm{e}}$ & 0 & $20.63 \pm 1.28^{\mathrm{d}}$ & 0 \\
\hline Bacillus cereus MIC7 & $16.26 \pm 0.81^{\mathrm{e}}$ & 0 & $28.9 \pm 0.77^{e}$ & 0 & 0 & $43.76 \pm 1.22^{b}$ & 0 \\
\hline Bacillus licheniformis MIC9 & $39.6 \pm 0.87 c$ & $32.76 \pm 1.45^{c}$ & $33.1 \pm 1.51 \mathrm{de}$ & $38.6 \pm 0.75^{d}$ & $31.0 \pm 0.57 \mathrm{~b}$ & 0 & 0 \\
\hline Pseudomonas aeruginosa MTCC 2581 & 0 & 0 & $40.93 \pm 0.98^{c}$ & $47.16 \pm 0.53^{c}$ & $36.33 \pm 0.57^{\mathrm{ab}}$ & 0 & $55.53 \pm 0.6^{b}$ \\
\hline Bacillus subtilis MTCC2763 & 0 & $11.83 \pm 0.43^{\mathrm{e}}$ & 0 & 0 & 0 & 0 & $41.60 \pm 1.09^{c}$ \\
\hline Bacillus coagulans MTCC 3543 & 0 & $21.8 \pm 1.03^{\mathrm{d}}$ & 0 & $48.43 \pm 0.69 \mathrm{bc}$ & 0 & 0 & $29.26 \pm 0.54^{\mathrm{e}}$ \\
\hline
\end{tabular}

spectrophotometer and test fungicides along with an adhesive carboxymethyl cellulose (CMC) were used to treat surface sterilized cucurbit seeds for 6 $\mathrm{h}$ on rotary shaker at $150 \mathrm{rpm}$. Seeds soaked in distilled water amended with CMC $(0.1 \mathrm{~g} / 10 \mathrm{ml})$ served as control (Ramamoorthy et al., 2002). The overnight drained seeds were subjected to germination test by paper towel method (ISTA, 2005) and seedling vigor was calculated as per mentioned by Abdul-Baki and Anderson (1973). Each rhizobacterial isolate was maintained in triplicate and all experiments were carried out in triplicate.

Statistical analysis: Statistical significance was measured by using GraphPad Prism 5 software and figure 2 by Origin 6. Data on the In-vitro mycelial inhibition of Fusarium spp. by PGPR and suppression of $F$. oxysporum pv. cucumerianum by fungicides were subjected to two way analysis variance (ANOVA). Mean values among treatments were compared by Tukey's HSD test $(\mathrm{p}<0.0001)$.

\section{RESULTS}

\section{In-vitro antagonistic activity}

Biological control: In the tested 11 isolates, three standard and eight isolated PGPR were used for the dual culture assay against Fusarium spp. Maximum inhibition was observed in case of $F$. verticillioides (52.36) and $F$. solani 2 (50.33) by Sarratia sp. MIC1. P. aeruginosa MIC2 inhibited all types of Fusarium spp. to the maximum extent. $P$. aeruginosa MTCC2581 inhibited mycelial growth of F. oxysporum 2 (55.53) maximum (Table 1). Control plates not treated with bacterial isolates were completely covered by phytopathogens. All the seven Fusarium spp. were not inhibited by single isolate, different isolates are effective on the different species. The mean mycelial growth inhibition of the Fusarium sp. bybacteria showed significant $(\mathrm{p}<0.0001)$.

Fungicides: The toxicity of the two tested fungicides carbendezim and mefenoxam + chlorothalonil used was evaluated against $F$. oxysporum.

The fungal radial growth rate was reduced as a result of increasing the fungicide concentration. The carbendazim inhibited $F$. oxysporum at $500 \mathrm{ppm}$ and mefenoxam + chlorothalonil inhibited at $1000 \mathrm{ppm}$ as maximum concentration. As summarised in Table 2. carbendezim was more effective against F. oxysporum as compared to mefenoxam + chlorothalonil in the different tested concentrations. 
Table 2. In-vitro suppression of Fusarium oxysporum pv. cucumeriamun by fungicides

\begin{tabular}{lll}
\hline \multirow{2}{*}{$\begin{array}{l}\text { oose } \\
\text { ppm }\end{array}$} & \% Inhibition & \\
\cline { 2 - 3 } & Mefenoxam+ chlorothalonil & Carbendezim \\
\hline Control & $86.78 \pm 0.69^{\mathrm{b}}$ & $84.52 \pm 0.66^{\mathrm{b}}$ \\
25 & $13.71 \pm 0.44^{\mathrm{f}}$ & $55.73 \pm 0.89^{\mathrm{e}}$ \\
50 & $45.83 \pm 0.58^{\mathrm{e}}$ & $61.50 \pm 0.68^{\mathrm{d}}$ \\
75 & $65.86 \pm 1.09^{\mathrm{d}}$ & $71.64 \pm 0.90^{\mathrm{c}}$ \\
100 & $75.52 \pm 0.62^{\mathrm{c}}$ & $86.33 \pm 0.62^{\mathrm{b}}$ \\
500 & $83.97 \pm 0.25^{\mathrm{b}}$ & $92.63 \pm 0.19^{\mathrm{a}}$ \\
1000 & $93.84 \pm 0.49^{\mathrm{a}}$ & \\
\hline
\end{tabular}

\section{Antibiotic Production}

Crude extract obtained from P. aeruginosa MIC2 was brownish colored having broad-spectrum antimicrobial activity. The TLC plates were analysed in chloroform: methanol (9:1) system (Fig.1) and revealed the presence of metabolite at $R_{f}-0.77$ confirmed by comparing with standard 2,4- diacetylphloroglucinol (DAPG) under UV at $254 \mathrm{~nm}$.

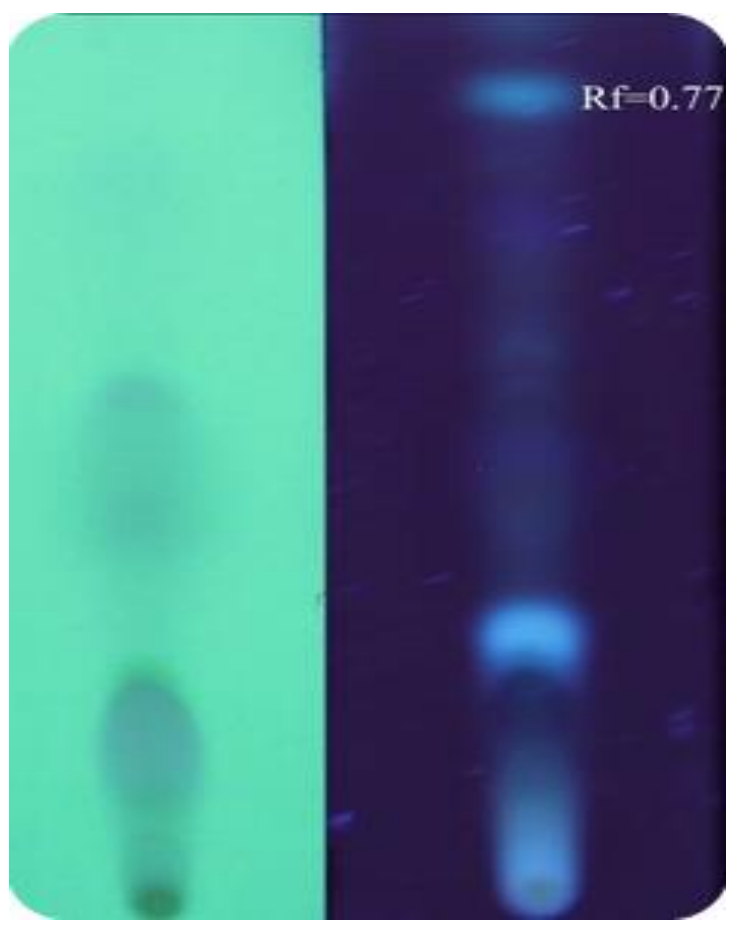

Figure 1. TLC summary of crude extracts of $P$. aeruginosa MIC2.

\section{In-vivo evaluation}

The 13 primed seeds showed no increase in germination and higher vigour index compared to control (Fig.2). Among these B. amyloliquefaciens MIC 6 and $P$. aeruginosa MTCC 2581 showed higher germination and vigour index. Both the chemicals showed maximum germination and vigour.

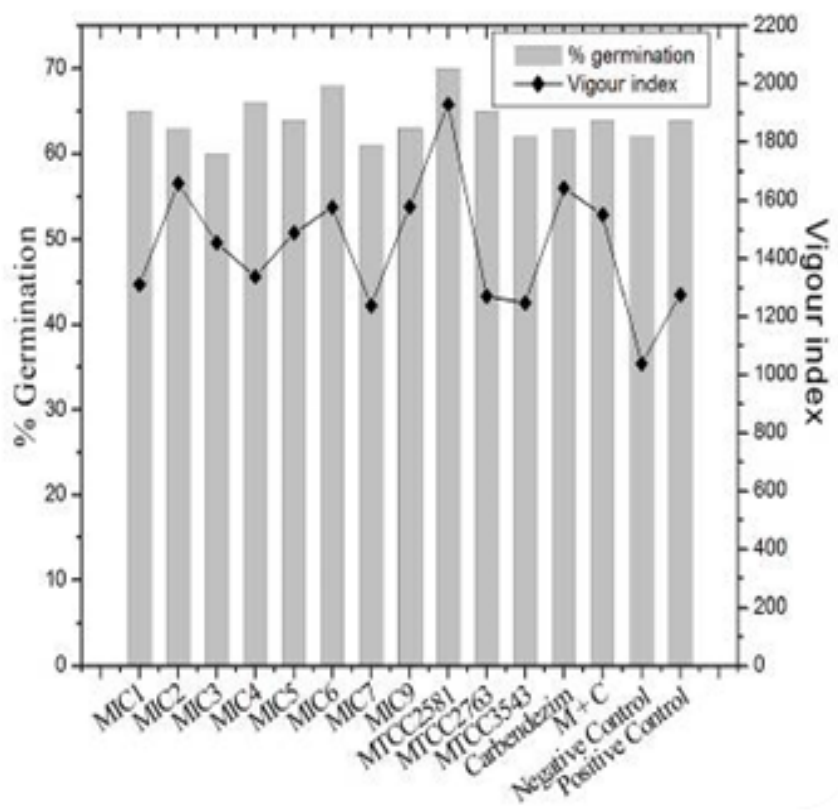

Figure 2. Effect of PGPR and fungicides priming on cucurbit seed germination and seedling vigour cucurbit after 8 days of germination.

\section{DISCUSSION}

Both the fungicides in all tested concentrations showed considerable effect on the growth of $F$. oxysporum compared to the control. Maximum inhibition of the colony growth by carbendazim at 500 ppm (92.63\%) and mefenoxam + chlorothalonil at $1000 \mathrm{ppm}(93.8 \%)$ was evident when compared to the control in the present study. Soil-borne diseases caused by $F$. oxysporum can be managed by using chemical fungicides. (Sultana and Ghaffar, (2010) reported that Carbendazim (100ppm) and Ridomil (500ppm) inhibited Fusarium solani a seed rot, seedling and root infection pathogen on gourds and cucumber. Carbendazim and Carbendazim + Mancozeb gave $100 \%$ inhibition of mycelial growth of $F$. solani at 0.2 and 0.3 $\%$ concentrations (Chavan et al., 2009). Among seven different fungicides, Bravo was most toxic to $F$. oxysporum CS-20 at 50 ppm were as Azoxystorin and Chlorothalonil inhibits at $10 \mathrm{ppm}$ or greater concentration compared to control (Fravel et al., 2005). $F$. graminearum, $F$. avenaceum and $F$. verticillioides isolates were tested at different concentrations of carbendazim, tebuconazole, flutriafol, metconazole and prochloraz by Ivic et al., 2011. Carbendazim was toxic at $10 \mathrm{mg} / \mathrm{l}$ with an IC50 of $F$. graminearum (0.39-1.41 $\mathrm{mg} / \mathrm{l}), \quad F$. avenaceum $(0.91-1.35 \mathrm{mg} / \mathrm{l})$ and $F$. 
verticillioides (0.47-0.6 mg/l). Shakoor et al. (2011) reported that fungicides Bavistin $(30 \mathrm{mg} / 10 \mathrm{ml})$ and Ridomil gold MZ (30 \& $40 \mathrm{mg} / 10 \mathrm{ml}$ ) concentrations controlled successfully Fusarium, Aspergillus as well as Myrothecium.

Eleven tested PGPR isolates, P. aeruginosa MTCC2581 controlled mycelial growth of $F$. oxysporum 2 and Sarratia spp. MIC1 inhibited F. verticilloids as well as F. solani 2 by more than 50\%. P. aeruginosa MIC2 suppressed the growth of all Fusarium spp. to the maximum (50.23).. The efficacy of PGPR strains Serratia UPMSP3, Erwinia UPMSP10 Pseudomonas UPMSP20 and UPMSP6 isolated by Yasmin et al., (2009) was reported to show antagonistic activity against species of Rhizoctonia and Pythium . Hariprasad et al., (2009) reported that the antagonistic activity of the $B$. amyloliquefaciens IRB36 (40\%), P. fluorescens IRB26 (43\%), P. fluorescens PSRB19 (31\%) and P. putida PSIRB15 against F.oxysporum in tomato. Among 14 PGPR isolates three inhibit the growth of $F$. oxysporum (20\%). Remaining isolates inhibited Sclerotium rolfsii and $R$. solani (11-20\%), being used as inoculants of soybean plant (Wahyudi et al., 2011). Singh et al., (1999) reported that Paenibacillus sp. 300 and Streptomyces sp. 385, suppressed Fusarium wilt of cucumber by chitinase and $\beta$-1,3-glucanase production.

Antifungal metabolites isolated from a small portion of the soil micro-flora were able to produce certain types of antibiotics, hydrogen cyanide, proteases and chitinolytic enzymes (Kumar et al., 2002; Hariprasad et al., 2013). Ayyadurai et al., (2005) reported that $P$. areroginosa produced an antimicrobial agent 2,4diacetylphloroglucinol (DAPG) in the chloroform: methanol (9:1) solvent system. In our study $P$. aeruginosa MIC2 with the same solvent system produced a metabolite at $\mathrm{R}_{\mathrm{f}}-0.77$ on TLC plate with a standard DAPG confirming the metabolite as DAPG (Fig.1).

In cucurbit seeds primed with PGPR, $P$. aeruginosa MTCC2581 showed maximum vigour followed by $P$. aeruginosa MIC2, B. amyloliquefaciens MIC6 and B. licheniformis MIC9. Compared to the control treated with sterile distilled water and pathogen. The roots from the control treatment rendered growth of $F$. oxysporum compared to an incidence upto $55 \%$ for plants treated with B. subtilis, B. licheniformis, B. cereus (Idris et al., 2007; Awatif and Al-Jedabi, 2009). Manikandan et al. (2010) reported that liquid formulation of $P$. fluorescens strain Pf1 applied against Fusarium wilt increased the tomato fruit yield compared to untreated control under glasshouse and field conditions. Chen et al. (2010) confirmed that among the 158 PGPR isolates, B. subtilis B579 suppressed the cucumber rot causing pathogen $F$. oxysporum $f$. sp. cucumerinum by production of hydrolytic enzymes. B. subtilis B579 increased the seedlings vigour and growth of plants.

In conclusion, among the tested PGPR strains $P$. aeruginosa MIC2 gave 35-50 \% inhibition of all Fusarium spp. and among the fungicides carbendizm inhibited $F$. oxysporum at lower concentration. The metabolite may be DAPG present in the crude extract of $P$. aeruginosa MIC2. Even though percent germination was not affected, vigour of plants primed with $B$. amyloliquefaciens MIC6 and P. aeruginosa MTCC2581 was considerably higher than the control. The two isolates were further tested for their performances in the field.

\section{REFERENCES}

Abdul-Baki, A.A. and J.D. Anderson. 1973. Vigour determination in soybean seed by multiple criteria. Crop Sci. 13: 630 - 633.

Awatif, A. and Al-Jedabi. 2009. Biological Control of Fusarium root-rot of Sorghum. Res. J. Agri. Biol. Sci. 5(4): 465 - 473.

Ayyadurai, N., P.R. Naik, M.S. Rao, R.S. Kumar, S.K. Samrat, M. Manohar and N. Sakthivel. 2005. Isolation and characterization of a novel banana rhizosphere bacterium as fungal antagonist and microbial adjuvant in micropropagation of banana. J. Appl. Microbiol. 100: 926-937.

Bafti, S.S., G.H.S. Bonjar, S. Aghighi, S. Biglari, P.R. Farrokhi and A. Aghelizadeh. 2005. Biological control of Fusarium oxysporum f.sp. melonis, the causal agent of root rot disease of greenhouse cucurbits in Kerman Province of Iran. Am. J. Biochem. Biotech. 1(1):22-26.

Chavan, S.C., Y.R. Hegde and S.K. Prashanthi. 2009. Management of wilt of patchouli caused by Fusarium solani. J. Mycol. Pl. Pathol. 39: 32 - 34.

Chehri, K., S. Abbasi, K.R.N. Reddy and B. Salleh. 2010. Occurrence and pathogenicity ofvarious pathogenic fungi on cucurbits from Kermanshah province, Iran. African J. Microbiol. Res. 4: 1215 122.

Chen, F., M. Wang, Y. Zheng, J. Luo, X. Yang and X. 
Wang. 2010. Quantitative changes of plant defense enzymes and phytohormone in biocontrol of cucumber Fusarium wilt by Bacillus subtilis B579. World J. Microbiol. Biotechnol. 26: 675- 684.

FAOSTAT (online). 2010. Food and Agriculture Organization of the United Nations - Rome, Italy. http://faostat.fao.org/default.aspx?lang=en.

Farrag, E.S.H. and M.H.A. Moharam. 2012. Pathogenic fungi transmitted through seeds and safely elimination by application of peppermint extract and oil. Not. Sci. Biol. 4(3): 83- 91.

Fravel, D.R., K.L. Deahl and J.R. Stommel. 2005. Compatibility of the biocontrol fungus Fusarium oxysporum strain CS-20 with selected fungicides. Biol. Control. 34: 16 -169.

Hamed, E.R., M.H.F. AbdEl-Sayed and H.S. Shehata. 2009. Suppression of Fusarium wilt of watermelon by biological and chemical control. $J$. Appl. Sci. Res. 5(10): 1816 -1825.

Hariprasad, P., S. Chandrashekar, S.B. Singh and S.R. Niranjana. 2013. Mechanisms of plant growth promotion and disease suppression by Pseudomonas aeruginosa strain 2apa. J. Basic Microbiol. 1 - 10.

Hariprasad, P., H.M. Navya, S.C. Nayaka and S.R. Niranjana. 2009. Advantage of using PSIRB over PSRB and IRB to improve plant health of tomato. Biol. Control. 50: 307-316.

Idris, A., N. Labuschagne and L. Korsten. 2009. Efficacy of rhizobacteria for growth promotion in sorghum under greenhouse conditions and selected modes of action studies. J. Agricul. Sci. 147: 17 - 30.

Idris, H.A., N. Labuschagne and L. Korsten. 2007. Screening rhizobacteria for biological control of Fusarium root and crown rot of sorghum in Ethiopia, Biol. Control. 40: 97-106.

ISTA. 2005. Proceedings of the International Seed Testing Association, International rules of seed testing. Seed Sci. Technol.15A: 1 - 9.

Ivic, D., Z. Sever and B. Kuzmanovska. 2011. In-vitro sensitivity of Fusarium graminearum, $F$. avenaceum and $F$. verticillioides to carbendazim, tebuconazole, flutriafol, metconazole and prochloraz. Pestic. Phytomed. (Belgrade), 26(1): 35- 42.
Khanzada, K.A., M.A. Rajput, G.S. Shah , A.M. Lodhi and F. Mehboob. 2002. Effect of seed dressing fungicides for the control of seed borne mycoflora of wheat. Asian J. Plant Sci. 1:441 - 444.

Kumar, N.R., A.V. Thirumalai and P. Gunasekaran. 2002. Genotyping of antifungal compounds producing plant growth promoting rhizobacteria Pseudomonas fluoresces. Curr. Sci. 82:1463 - 1468.

Kundu, S.K. 2012. Spatio-temporal dynamics of vegetable crop production in India. Intl. Multidisciplinary Res. J. 2(7):54 - 57.

Mahfooz, S., D.K. Maurya, A.K. Srivastava, S. Kumar and D.K. Arora. 2011. A comparative in-silico analysis on frequency and distribution of microsatellites in coding regions of three formae speciales of Fusarium oxysporum and development of EST-SSR markers for polymorphism studies. FEMS Microbiology Letters. $1-7$.

Manikandan, R., D. Saravanakumar, L. Rajendran, T. Raguchander and R. Samiyappan. 2010. Standardization of liquid formulation of Pseudomonas fluorescens Pf1 for its efficacy against Fusarium wilt of tomato. Biol. Control. 54: 83 - 89.

Ramamoorthy, V., T.R. Raguchander and R. Samiyappan. 2002. Induction of defense-related proteins in tomato roots treated with Pseudomonas fluorescens Pf1 and Fusarium oxysporum $f$. $s p$. lycopersici. Plant Soil. 239: 55 - 68.

Santos, F.M.A., B. Ramos, M.A.G. Sanchez, A.P. Eslava and J.M.D. Minguez. 2002. A DNA based procedure for in planta detection of Fusarium oxysporum $f$. $s p$. phaseoli. Phytopathol. 92: 237 - 244.

Shakoor, S., S. Chohan, A. Riaz, R. Perveen, S. Naz, M.A. Mehmood, M.S. Haider and S. Ahmad. 2011. Screening of Systemic Fungicides and Biochemicals against Seed Borne Mycoflora Associated with Momordica charantia. African J. Biotechnol. 10 (36): 6933 - 6940.

Singh, P.P., Y.C. Shin, C.S. Park and Y.R. Chung. 1999. Biological control of Fusarium wilts of cucumber by chitinolytic bacteria. Phytopathol. 89:92 - 99.

Sultana, N. and A. Ghaffar. 2010. Effect of fungicides, microbial antagonists and oilcakes in the control of Fusarium solani, the cause of seed rot, seedling and root infection of bottle gourd, bitter gourd and cucumber. Pak. J. Bot. 42(4): 2921 - 2934. 
Tamietti, G. and D. Valentino. 2006. Soil solarisation as an ecological method for the control of Fusrium wilt of melon in Italy, Crop Prot. 25: 389 - 397.

Wahyudi, A.T., R.I. Astuti and Giyanto. 2011. Screening of Pseudomonas sp. isolated from rhizosphere of soybean plant as plant growth promoter and biocontrol agent. Ameri. J. Agri. Biol. Sci. 6 (1): 134 $-141$.

Yasmin, F., R. Othman, K. Sijam and M.S. Saad. 2009. Characterization of beneficial properties of plant growth-promoting rhizobacteria isolated from sweet potato rhizosphere. Afr. J. Microbiol. Res. 3(11):815-821.

Zhao, Q., C. Dong, X. Yang, X. Mei, W. Ran, Q. Shen and Y. Xu. 2011. Biocontrol of Fusarium wilt disease for Cucumis melo melon using bio-organic fertilizer. Appl. soil Ecol. 47:67-75.

Zitter, D.L, D.L. Hopkins and C.E. Thomas. 1996. Compendium of cucurbit diseases. APS Press, St. Paul, MN. pp. 732. 